\title{
A Review on the Production and Uses of Herbal Teas
}

\author{
Abdela Befa Kinki \\ Researcher I at Ethiopia Institute of Agriculture Research, Wondo Genet Agriculture Research CenterP.O.Box: 198, Shashamene, Ethiopia \\ Corresponding Author: Abdela Befa Kinki, Researcher I at Ethiopia Institute of Agriculture Research, Wondo Genet Agriculture Research \\ CenterP.O.Box: 198, Shashamene, Ethiopia.
}

Received date: March 11, 2021; Accepted date: March 18, 2021; Published date: March 30, 2021

Citation: Abdela Befa Kinki, (2021) A Review on the Production and Uses of Herbal Teas. J. Nutrition and Food Processing, 4(2); DOI: $10.31579 / 2637-8914 / 045$

Copyright: () 2021 Abdela Befa Kinki, This is an open access article distributed under the Creative Commons Attribution License, which permits unrestricted use, distribution, and reproduction in any medium, provided the original work is properly cited.

\begin{abstract}
Herbs are the fresh or mixtures of dried leaves, seeds, grasses, nuts, barks, fruits, flowers, or other botanical elements. The production and uses of herbs are not new to the Worlds and Ethiopia. However, there is no such compiled information about herbal tea and its uses in Ethiopia. Herbs have a long history of both culinary use and health benefits, as well as acting as preservatives. Many herb plants are widely used as cooking to enhancing the flavor of foods including meats, sauces, vegetables, and health benefits by ensuring protection against harmful free radicals which consequently damaging of cellular structures, which contributes to the development of many diseases, have analgesic, anti-inflammatory, anti-bacterial, anti-viral and antiallergic. Drinking herbal teas has the advantage of boosting energy levels and invigorating the body, quenching the body by preventing hydration of the body, it promotes night sleep due to caffeine-free and it also has distinctive sensory qualities due to it contain the volatile fractions of various aroma active compounds. Herbal tea can be prepared by infusion or decoction using water on the whole or reduced to a suitable size and allowing too steep for a defined period. This review gives information on the production and the uses of herbal in the form of teas.
\end{abstract}

Keywords: Herbal tea; Infusions; Medicine, Phytochemicals; Production

\section{Introduction}

Herbs are the fresh or mixtures of dried leaves, seeds, grasses, nuts, barks, fruits, flowers, or other botanical elements [1-3]. Based on different theoretical, cultural, and religious principles peoples are using herbs for the preparation of refreshing drinks and medicinal purposes [4-7]. Herbal tea can be prepared by infusions or decoction $[3,8,9]$. Herbal teas have been extensively consumed because of their health-promoting and sensory characteristics $[3,10]$. However, there is no sufficiently detailed information on herbal tea production and herbal tea use in Ethiopia.

\section{History and Production of Herbal Tea}

The people have been collecting herbs for their personal use or to provide income for their families or members during the former Socialist Republic of Yugoslavia, as well as today, B\&H is a supplier of mainly unprocessed medicinal and aromatic plants [10-12]. The main herbal tea producing countries are Asia:- Bangladesh, China, India, Indonesia, Sri Lanka, Viet Nam, Africa:- Burundi, Kenya, Malawi, Rwanda, Tanzania, Uganda, Zimbabwe, and South America:- Argentina, Brazil, and others [5].

\subsection{Herbal tea production in Ethiopia}

The cultivation and use of herbs are not new to Ethiopia and as old as the other crop [13, 14]. Ethiopia has a long history of herb production for the domestic market and has unique, indigenous herbs that have been exported for centuries to countries in the Middle East, and exports to
Europe have developed over the past twenty years $[15,16]$. Most of the herbs have been used as a source of traditional medicine to treat different diseases $[17,18]$. In Ethiopia, several culinary herbs are produced: chervil, chives, coriander, dill, green basil, lovage, mint, oregano, rocolla, thyme, Vernonia [16].

\subsection{The Chemical Composition and the use of Herbal Tea}

Herbal tea has different chemical compositions; -phytochemical and antioxidant screening results showed the presence of tannins, steroids, terpenoids, saponins, cardiac glycosides, flavonoids, alkaloids, and phlobatannins [19-21]. The chemical composition includes; moistures, protein, carbohydrates, fiber, and ash content, minerals such as chromium $(\mathrm{Cr})$, iron $(\mathrm{Fe})$, manganese $(\mathrm{Mn})$, Lead $(\mathrm{Pb})$, and zinc $(\mathrm{Zn})[19,20]$.

Herbs have a long history of both culinary use and of providing health benefits, as well as acting as preservatives mainly with Ethiopia [10, 22]. Many herb plants are widely used as cooking to enhancing the flavor of foods including meats, sauces, vegetables, and desserts [10, 23, 24]. Beyond acting as a replacement for salt, the nutritional contribution of these dietary plants has in the past been deemed negligible probably because of the relatively small, although increasing amounts consumed [16, 22-24]. Herbal teas have health benefits due to specific active substances phytochemicals [24-27]. Among the phytochemical substances, phenolic acids and flavonoids, are the major groups of natural 
components in plants that have received increasing interest over the last decades due to free radical scavenging properties. These phytochemicals are excellent to ensuring protection against harmful free radicals, which, through reactions with proteins, lipids, and saccharides, lead to their oxidation and consequently to the damaging of cellular structures, which contributes to the development of many diseases, have analgesic, antiinflammatory, anti-bacterial, anti-viral and antiallergic. Drinking herbal teas have also the advantage of boosting energy levels and invigorating the body, quenching the body by preventing hydration of the body, it promotes night sleep due to caffeine-free and antimicrobials activity [8, $24,28]$. No adverse statements have been reported for the drinking of herbal tea and herbal tea combinations can be used in minor complaints affecting [29, 30].

\subsection{Preparation of herbal tea}

Extraction is liquid preparations extemporaneously prepared by boiling herbal substance(s) with water on the whole or reduced to a suitable size and allowing too steep for a defined period, usually 5 to 15 minutes as they have a beautiful fragrance and are very appealing when not otherwise specified $[28,31]$. The extraction of tea is determined by various factors, such as the tea-to-water ratio, length of infusion, temperature of infusion, type of infused water, and type of tea [32-36].

\subsection{Sensory attributes of herbal tea}

A wide variety of plant materials with distinctive sensory qualities exist as potential ingredients of herb tea and its volatile fractions of various teas contain more than 50 aroma active compounds which give sweet, fragrant, malty, strong, full-bodied, spicy, fragrantly fruity, fresh, herbaceous, smoothly fragrant, deep, astringent, grassy tasting, smoky, savory strength, bitter and refreshing( [14, 37, 38].

\section{Conclusion}

The information presented in this review shows that herbal tea is the oldest and cheapest healthy beverage in the world. They are prepared by infusion of tea or herbal alone or by combining with different ingredients. Due to it is an affordable source of phytochemicals, antioxidants, minerals, vitamins, aroma, and other compounds it is useful as a nutriceutical function. Further reviewing, especially well-conducted documents and needs to be performed to provide compelling evidence for the nutritional profile of herbal tea and creating awareness.

Acknowledgment: -The author like to thanks Mr.Roba Tussa and other Wondo Genet Agricultural Research Center researcher those given to me advice and constant support when I was reviewing this paper.

\section{Reference}

1. Peter KV. (2012)Handbook of herbs and spices: Elsevier.

2. Peter K. Handbook of herbs and spices: Woodhead publishing; 2006.

3. Ravikumar C. (2014) Review on herbal teas. Journal of Pharmaceutical Sciences and Research. 6(5):236.

4. Kamiloglu S, Toydemir G, Boyacioglu D, Capanoglu E. (2012) Health perspectives on herbal tea infusions. Phytotherapeutics.

5. Hicks A. (2009) Current status and future development of global tea production and tea products. AU JT.; 12(4):251-264.

6. Bender M, Heenen P-H, Reinhard P-G. (2003). Self-consistent mean-field models for nuclear structure. Reviews of Modern Physics. 75(1):121.

7. Kumar S, Pandey AK. (2013) Chemistry and biological activities of flavonoids: an overview. The Scientific World Journal.

8. Killedar SG, Pawar AV, Suresh Killedar C. (2017) Preparation of Herbal Tea from Mulberry Leaves. Journal of Medicinal Plants. 5(2):325-328.
9. Sujkowska-Rybkowska M, Borucki W. (2014) Accumulation and localization of extensin protein in apoplast of pea root nodule under aluminum stress. Micron. 67:10-19.

10. Tapsell LC, Hemphill I, Cobiac L, Sullivan DR, Fenech M, Patch CS, et al. (2006) Health benefits of herbs and spices: the past, the present, the future..

11. Rajić M, Jokić S, Bilić M, Vidović S, Bošnjak A, Adžić D. (2014). The application of Herzegovinian herbs in production of tea mixes. Hrana u zdravlju i bolesti: znanstveno-stručni časopis za nutricionizam i dijetetiku. 3(1):31-37.

12. Tadesse M, Hunde D, Getachew Y. (2005) Survey of medicinal plants used to treat human diseases in Seka Chekorsa, Jimma Zone, Ethiopia. Ethiopian Journal of Health Sciences. 15(2).

13. Endashaw B. (2007) Study on actual situation of medicinal plants in Ethiopia. Japan Association for International Collaboration of Agriculture and Forestry. 2:1-9.

14. Yemane H. (2015) Effect of herbal plants on quality and microbial safety of milk in eastern Zone of Tigray, Ethiopia: ILRI.

15. Bekele E. (2007) Study on actual situation of medicinal plants in Ethiopia. Japan Association for International Collaboration of Agriculture and Forestry.54-60.

16. Nigus K, Chandravanshi BS. (2016) Levels of fluoride in widely used traditional Ethiopian spices. Fluoride. 49(2):165.

17. Abera B. (2014) Medicinal plants used in traditional medicine by Oromo people, Ghimbi District, Southwest Ethiopia. Journal of ethnobiology and ethnomedicine. 10(1):40.

18. Senbeta F, Gole TW, Denich M, Kellbessa E. (2013). Diversity of useful plants in the coffee forests of Ethiopia. Ethnobotany Research and Applications. 11:049-69.

19. Samali A, Kirim RA, Mustapha K. (2012). Qualitative and quantitative evaluation of some herbal teas commonly consumed in Nigeria. African Journal of Pharmacy and Pharmacology. 6(6):384-388.

20. Ahmad S, Khader JA, Gilani SS, Khan S, Noor S, Ullah R, et al. (2012). Determination of mineral and toxic heavy elements in different brands of black tea of Pakistan. African Journal of Pharmacy and Pharmacology.

21. Altemimi A, Lakhssassi N, Baharlouei A, Watson DG, Lightfoot DA. (2017) Phytochemicals: Extraction, isolation, and identification of bioactive compounds from plant extracts. Plants. 6(4):42.

22. Norris JA, Dahl W. Shopping for Health: Herbs and Spices. EDIS. 2013; 2013(4).

23. Opara EI, Chohan M. (2014).Culinary herbs and spices: their bioactive properties, the contribution of polyphenols and the challenges in deducing their true health benefits. International journal of molecular sciences. 15(10):19183-202.

24. Kozak M, SOBCZAK P, Krajewska M, ŚLASKA-GRZYYWNA B, Wojtowicz A, ŻUKIEWICZ-SOBCZAK W. (2017) Evaluation of health promoting properties and quality of herbal teas obtained from fine-grained fraction of herbs. Journal of Central European Agriculture.

25. Sepahpour S, Selamat J, Manap A, Yazid M, Khatib A, Abdull Razis AF.(2018) Comparative analysis of chemical composition, antioxidant activity and quantitative characterization of some phenolic compounds in selected herbs and spices in different solvent extraction systems. Molecules. 23(2):402.

26. Onaolapo A, Onaolapo O. (2019) Herbal Beverages and Brain Function in Health and Disease. Functional and Medicinal Beverages: Elsevier. p. 313-349.

27. Saraf S. (2010) Applications of novel drug delivery system for herbal formulations. Fitoterapia. 81(7):680-689. 
28. Omogbai BA, Ikenebomeh M. (2013). Microbiological characteristics and phytochemical screening of some herbal teas in Nigeria. European Scientific Journal. 9(18).

29. Bhat R, Moskovitz G. (2009) Herbal medicinal teas from South Africa. Phyton (Buenos Aires). 78:67-73.

30. Mabey R, McIntyre A, McIntyre M. (1998) The New Age Herbalist: How to use herbs for healing, nutrition, body care, and relaxation: Simon and Schuster.

31. Wilhelm JJ. (2010). Ezra Pound in London and Paris, 1908-1925: Penn State Press.

32. Jaganyi D, Mdletshe S. (2000) Kinetics of tea infusion. Part 2: the effect of tea-bag material on the rate and temperature dependence of caffeine extraction from black Assam tea. Food Chemistry. 70(2):163-165.

33. Sharma V, Gulati A, Ravindranath S. (2005) Extractability of tea catechins as a function of manufacture procedure and temperature of infusion. Food chemistry. 93(1):141-148.
34. Weerts A, Martin D, Lian G, Melrose J. (2005). Modelling the hydration of foodstuffs. Simulation Modelling Practice and Theory. 13(2):119-128.

35. Ezeike C, Aguzue O, Thomas S. (2011) Effect of brewing time and temperature on the release of manganese and oxalate from Lipton tea and Azadirachta indica (Neem), Phyllanthus amarus and Moringa oleifera blended leaves. Journal of Applied Sciences and Environmental Management. 15(1).

36. Xiong W, Quan D, Patel DC. (2001) Effervescent green tea extract formulation. Google Patents.

37. Lee SM, CHUNG SJ, LEE OH, LEE HS, KIM YK, KIM KO. (2008) Development of sample preparation, presentation procedure and sensory descriptive analysis of green tea. Journal of sensory studies. 23(4):450-467.

38. Imram N. (1999). The role of visual cues in consumer perception and acceptance of a food product. Nutrition \& Food Science. 